\title{
The diet of the South American sea lion (Otaria flavescens) at Río Negro, Patagonia, Argentina, during the winter-spring period
}

\author{
Raimundo L. Bustos ${ }^{1}$, Gustavo A. Daneri ${ }^{1}$, Alejandra V. Volpedo ${ }^{2}$, Ana Harrington ${ }^{1} \&$ Esperanza A. Varela ${ }^{1}$ \\ 1. Museo Argentino de Ciencias Naturales "Bernardino Rivadavia", División Mastozoología, Av. Angel Gallardo 470 (C1405DJR), Buenos Aires, Argentina. (rlucasbustos@gmail.com, \\ gdaneri@macn.gov.ar, ana_harrington@hotmail.com, eavarela@macn.gov.ar) \\ 2. Centro de Estudios Transdisciplinarios del Agua - CONICET, Facultad de Ciencias Veterinarias, Universidad de Buenos Aires, Av. Chorroarín 280 (1428), Buenos Aires, Argentina. (avolpedo@gmail.com)
}

\begin{abstract}
The South American sea lion, Otaria flavescens (Shaw, 1800) population is steadily expanding along the Patagonian coast of Argentina in the last decades. However, little is known about the feeding ecology of the species in the area. The aim of this study was to analyze the food habits of $O$. Alavescens from 91 scats collected at Río Negro province, during the winter and spring of 2005. Fish occurred in $96 \%$ of scats containing prey remains, followed by cephalopods (26\%). Raneya brasiliensis (Kaup, 1856) was the most frequent and abundant species occurring in $58.6 \%$ of samples and constituting almost $50 \%$ of fish predated. Second in importance were Porichthys porosissimus (Cuvier, $1829)$ and Cynoscion guatucupa (Cuvier, 1830) in terms of occurrence (\%FO 20.7) and numbers $(29.6 \%)$ respectively. The squid Loligo gahi (d'Orbigny, 1835) was the most frequent cephalopod prey (42.1\%), whereas Octopus tehuelchus (d'Orbigny, 1834) was the most abundant (77\%). The higher amount and diversity of prey found in the spring in comparison with the winter season might be related to a higher feeding activity of seals or to a seasonal increase in food availability in the area.
\end{abstract}

KEYWORDS. Trophic ecology, Pinnipedia, fishes, cephalopods.

RESUMEN. Dieta del lobo marino de un pelo sudamericano (Otaria flavescens) en Río Negro, Patagonia, Argentina, durante el invierno y primavera. La población del lobo marino de un pelo sudamericano Otaria flavescens (Shaw, 1800) ha experimentado un crecimiento continuo en las ultimas décadas en las costas de la Patagonia Argentina. Sin embargo, poco se conoce sobre la ecología trófica de la especie en el área. El objetivo de este estudio fue analizar los hábitos alimentarios de O. flavescens a partir de 91 fecas colectadas en la provincia de Río Negro, durante el invierno y la primavera del 2005. Los peces estuvieron presentes en el $96 \%$ de las fecas que contenían remanentes presas, seguidos por los cefalópodos (26\%). Raneya brasiliensis (Kaup, 1856) fue la especie mas frecuente y abundante ocurriendo en el 58.6\% de las muestras y constituyendo casi el $50 \%$ de los peces predados. Le siguieron en importancia Porichthys porosissimus (Cuvier, 1829) y Cynoscion guatucupa (Cuvier, 1830) en términos de frecuencia de ocurrencia (\%FO 20,7) y abundancia numérica (29,6\%) respectivamente. El calamar Loligo gahi (d'Orbigny, 1835) fue el cefalópodo presa mas frecuente (42,1\%), mientras que Octopus tehuelchus (d'Orbigny, 1834) fue el mas abundante (77\%). La mayor cantidad y diversidad de presas observada en primavera en comparación con el periodo invernal podría estar relacionada a una mayor actividad de forrajeo de los lobos o a un incremento en la disponibilidad de presas en el área.

PALABRAS-CLAVE. Ecología trófica, Pinnipedia, peces, cefalópodos.

The knowledge of the structure and function of marine ecosystems requires information on the trophic relationships between key species (RACLOT et al., 1998). The pinnipeds are top predators in several marine ecosystems, and therefore have a potential influence over the trophic and population dynamics (BEGON et al., 1996). Consequently the study of their feeding habits constitutes an important tool to interpret their ecological role in marine ecosystems.

The South American sea lion Otaria flavescens is the most abundant otariid in the argentine marine coast and is widely distributed from Mar del Plata, Buenos Aires province $\left(38^{\circ} 12^{\prime} \mathrm{S}, 57^{\circ} 33^{\prime} \mathrm{W}\right)$ to Tierra del Fuego province $\left(52^{\circ} 27^{\prime} \mathrm{S}, 69^{\circ} 25^{\prime} \mathrm{W}\right)$ in around one hundred rookeries (DANs et al., 1996; ReYes et al., 1999; SCHIAVIni et al., 2004). The Southern sea lion population in the argentine coast was dramatically reduced between the 30' and 50's, and protected during the 1970s through an Executive Order $n^{\circ} 1.216$. Although the population of $O$. flavescens is currently increasing, it has not reached yet its original level (CRESPO \& PEDRAZA, 1991; Dans et al., 2004; CRESPO et al., 2012).

The current total population number in the argentine coast was estimated in 125,000 individuals, according to information from censuses carried out in northern and central Patagonia (DANs et al., 2004; CRESPO et al., 2012).

Since the food availability in the ocean is one the major factors that may influence the marine mammals population fluctuations, the study of the feeding ecology of the South American sea lion is extremely important. In this regard, CRespo \& PedrazA (1991), attributed the very slow recovery in recent years of the population of $O$. flavescens in the Patagonian coast to diverse factors such as the expansion of fishing activities in the area, as well as the partial overlapping of spatial and trophic niche with other predator species, e.g. little cetaceans [vg. Delphinus delphis (Linnaeus, 1758), Cephalorhyncus obscurus (Gray, 1828)], seabirds [Spheniscus magellanicus (Forster, 1781)] and seals [Mirounga leonina (Linnaeus, 1758)]. Moreover, recent studies using stable isotope analyses have indicated that $M$. leonina and $O$ flavescens have similar isotopic profiles, which would indicate that both species include in their diet prey taxa of relatively similar trophic level (Lewis et al., 2006).

Dietary studies of $O$. flavescens in general suggest that it has a generalist and opportunistic feeding behavior, being fish, cephalopods and crustaceans the most common prey taxa (George-Nascimento et al., 
1985; Thompson et al., 1998; Koen Alonso et al., 2000; NAYA et al., 2000; SuÁrez et al., 2005; Sото et al., 2006).

Furthermore, some of these studies have reported sex differences in the food habits, attributing this, at least partially, to different use of foraging areas (KoEN Alonso et al., 2000; NAYA et al., 2000; Drago et al., 2009). CAMPAGNA et al. (2001) analyzing the movement patterns and locations at sea of $O$. flavescens, found differences in relation to the distance and duration average of foraging trips among sexes.

In addition it is noted that numerous studies have addressed the seasonal and interannual variation in the diet of different pinniped species (REID \& ARNould, 1996; Dellinger \& Trillmich, 1999; Daneri et al., $2005,2008)$. It is worth mentioning that the spring season coincides with the pre-reproductive period and is the time that individuals should store as much energy as possible to meet the cost of the reproductive phase, during which they fast. This has been reported for some pinniped species (e.g. Sergeant, 1973) and has also been suggested specifically for $O$. flavescens (XIMÉNEZ, 1976; GeORge-NASCimento et al., 1985). To date dietary studies of $O$. flavescens populations distributed along the Argentine coast are scarce and most of them have reported preliminary conclusions (KoEn Alonso et al., 2000; SuÁrez et al., 2005; Drago et al., 2010; Romero et al., 2011). Thus, this is the first detailed study that reports the winter and spring diet of $O$. flavescens on the Patagonian coast.

The aims of this research were (1) to analyze the diet of $O$. flavescens on the coasts of Río Negro province, (2) to establish whether or not there existed seasonal differences (winter vs spring) in the composition of its diet.

\section{MATERIALS AND METHODS}

The present study was carried out in the sea lion rookery of Punta Bermeja $\left(41^{\circ} 09^{\prime} \mathrm{S}, 63^{\circ} 05^{\prime} \mathrm{W}\right)$, located within a Natural Protected Area dependent of the Consejo de Ecología y Medio Ambiente (CODEMA) of Río Negro Province (Fig. 1). This colony represents an important reservoir of juveniles, with small breeding areas in constant growth (DANs et al., 2004). This is a permanent colony with seasonal variation in number of individuals through the year.

A total of 91 fresh scats were collected, in August 2005 (winter, $\mathrm{n}=46$ ) and November 2005 (spring, $\mathrm{n}=45$ ). During these collection periods the maximum number of sea lions counted ashore in each season was 4,082 and 4,755 respectively. In both seasons juveniles and females represented together almost $95 \%$ of the colony, the remainder being represented by subadult and adult males. The different sex-age categories of sea lions were classified according to DANS et al. (2004).

The samples were preserved in $70 \%$ ethanol and brought to the laboratory for further examination. Hard remains were recovered using sieves of different mesh size $(2.5-0.5 \mathrm{~mm})$ and rising water. Alimentary remnants found were classified according to their origin in fish (bones, otoliths, scales and eye lens), cephalopods (beaks, eye lens and pens), crustaceans (remains of exoskeleton) and mollusks "other than cephalopods" (shells). Whenever was possible, the different prey taxa were identified to the lowest taxonomical level. Fish otoliths and cephalopod beaks were used for prey identification by comparison with available catalogues (Torno, 1976; Clarke, 1986; Hecht, 1987; Baldas et al., 1997; VolPedo \& ECheVerría, 2000; XAVIER \& Cherel, 2009) and two reference collections (Laboratorio de Sistemática, Anatomía y Bioecología de Mamíferos Marinos, División Mastozoología del Museo de Ciencias Naturales "Bernardino Rivadavia" and Laboratorio de Vertebrados (COLV) FCEN - Universidad de Buenos Aires).

Total length and weight of consumed prey were estimated for the main fish species using regression equations that relate otolith length to total length and between fish total length and wet mass after ToRno (1976), Hecht (1987), Pineda et al. (1996), Baldas et al. (1997), Koen Alonso et al. (2000), and Volpedo \& ECHEVERRíA (2000). It is worth mentioning that otoliths were assigned to three categories in increasing order of erosion: (1) good: little or no erosion with intact margins and medial relief; (2) some signs of smoothing of margins and medial relief; and (3) heavily eroded: with no medial relief and margin generally rounded. A correction factor was applied to compensate for this erosion (10\% for group 1 and $20 \%$ for group 2 ). Those included in the third group were not taken into account for the estimation of fish size and biomass (REID \& ARnould, 1996; Daneri et al., 2008). As regards to cephalopod prey taxa, published allometric equations were used to relate the lower rostral length (LRL) to dorsal mantle length (DML in $\mathrm{mm}$ ) and wet mass (W in $g$ ) for squids. In the case of octopodids instead, the equations used related lower hood length (LHL) to wet mass (W in g) (Clarke, 1986; Pineda et al., 1996). In

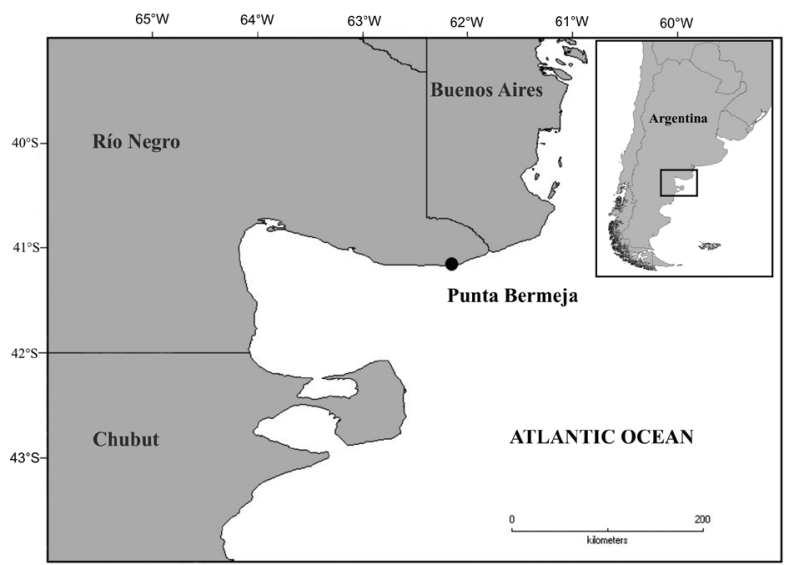

Fig. 1 Map of study area showing location of Punta Bermeja rookery, Río Negro Province, Argentina. 
some cases where the equation to estimate size and biomass of a given species were not available, we used those from morphologically and phylogenetically related species. Specifically, in Porichthys porosissimus (Cuvier, 1829) and Octopus tehuelchus, we used equations for Porichthys margaritatus (Richardson, 1844) and Octopus vulgaris (Lamarck, 1798), respectively. Furthermore, for both fish and cephalopod taxa the percentage frequency of occurrence $(\% \mathrm{FO})$ and percentage of the total number $(\% \mathrm{~N})$ were calculated.

To estimate the number of individuals we considered the otoliths that were present in greater number, (left or right) and in the case of cephalopods the number of lower beaks. Additionally, for each season, the index of relative importance (IRI), of each prey species was calculated (PINKAs et al., 1971).

$$
\mathrm{IRI}=(\% \mathrm{~N}+\% \mathrm{~W}) \% \mathrm{FO},
$$

where:

$\% \mathrm{FO}$ is the percentage of scats containing otoliths or beaks of a given species, the numerical abundance $(\% \mathrm{~N})$ is calculated as the percentage of otoliths or beaks of each taxa within the total number of otoliths and beaks, and $\% \mathrm{~W}$ is the wet mass. It is worth mentioning that, for an easier interpretation of the IRI, this index was expressed on a percent basis (\%IRI) following CORTES (1997).

Furthermore, the diversity of the trophic spectrum of the fish component of the seals diet at each season was calculated by using the Shannon-Wiener Index $\left(\mathrm{H}^{\prime}\right)$

$$
H^{\prime}=-\sum_{i=1}^{K} p_{i} \log p_{i}
$$

where:

$\mathrm{k}$ is the number of categories

$p_{i}$ is the proportion of observations found in category $i$

The term diversity is defined by the variety of items identified in each scats.

Finally, to assess the existence of seasonal variation in the frequency of occurrence of the three main categories of prey taxa considered (fish, cephalopods and crustaceans) a Chi-square test was performed.

\section{RESULTS}

Hard remains were found in $80 \%$ of all scats collected. A total of nine different prey species were identified (teleosts and cephalopods).

Fish were the most frequent prey item, occurring in $96 \%$ of scats during the overall study period, followed by cephalopods, which occurred in $26 \%(n=19)$ (Fig. 2). Fish were represented by a total of 310 otoliths during the whole study period. A total of 7 teleost species could be identified (Tab. I). Raneya brasiliensis was

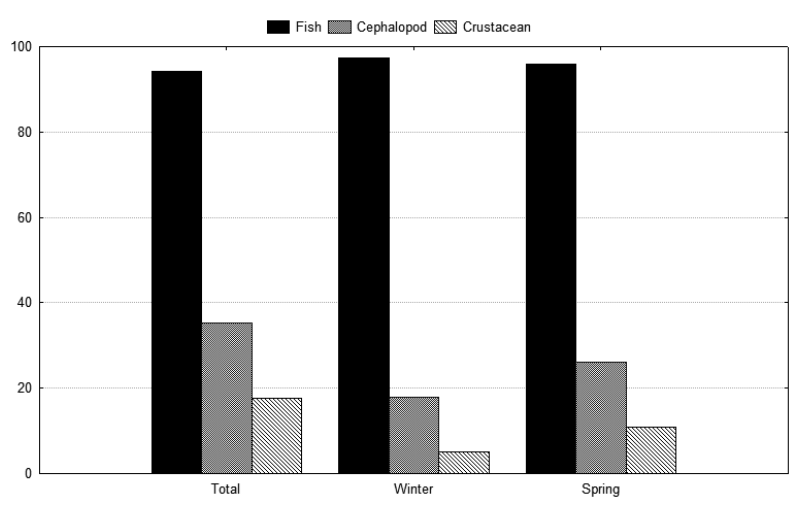

Fig. 2 Percent frequency of occurrence of the three main prey items recovered from scats of Otaria flavescens (Shaw, 1800).

the most frequent and abundant species $(\% \mathrm{FO}=58.6$, $\% \mathrm{~N}=49.7)$, followed in terms of frequency occurrence by Porichthys porosissimus $(\% \mathrm{FO}=20.7)$, Cynoscion guatucupa $(\% \mathrm{FO}=17.2)$ and Eleginops maclovinus (Valenciennes, 1830) $(\% \mathrm{FO}=10.3)$.

All these species constituted together more than $93 \%$, in numerical abundance, of the total amount of fish preyed on during the whole study period. Furthermore, C. guatucupa and E. maclovinus were the two fish species with highest value of IRI (Tab. I).

In total, cephalopods were represented by 111 beaks (upper $n=50$ and lower $n=61$ ) which were removed from 15 scats. The identification of lower beaks indicated the presence of two species of squid, Loligo gahi and a representative of the family Ommastrephidae and a single species of octopus, Octopus tehuelchus. The squid $L$. gahi was the most frequent $(\% \mathrm{FO}=$ 42.1) cephalopod prey, constituting 54.8\% in terms of biomass whereas the octopod Octopus tehuelchus was the most abundant, representing $77 \%$ in numbers and contributing $58 \%$ to the percentage value of the total IRI (Tab. I). Crustaceans appeared in $11 \%$ of the scats that presented hard remains. The estimated total lengths of the main fish prey species of $O$. flavescens during the study period are shown in Tab. II. Also, the estimated length frequency distributions of $C$. guatucupa and $R$. brasiliensis consumed by $O$. flavescens are indicated in figures 3 and 4 .

Winter. For the winter season, a total of 48 otoliths were recovered at a rate of 1.26 otoliths per scat containing fish remains $(n=38)$. Otoliths from four different fish species were identified. Raneya brasiliensis was the most frequent $(\% \mathrm{FO}=33.3)$, followed by $E$. maclovinus $(\% \mathrm{FO}=25)$. The most numerically abundant species was $P$. porosissimus $(\% \mathrm{~N}=20.7)$ (Tab. I). The highest values of relative importance corresponded to $E$. maclovinus with a percentage contribution to total IRI of $45.4 \%$ followed by $P$. porosissimus with $38.3 \%$ IRI.

In regard to cephalopods, these were represented by six beaks (upper $n=3$; lower $n=3$ ), which were identified as L. gahi and a representative of the family Ommastrephidae (Tab. I). These beaks were recovered at a rate of 0.5 beaks per scat containing cephalopod remains. 
Tab. I. Composition of prey remains recovered from scats of Otaria flavescens (Shaw, 1800) on Río Negro province, Argentina (\%FO, percent frequency of occurrence; $\% \mathrm{~W}$, percentage of total mass; $\% \mathrm{~N}$, percentage of the total number; $\%$ IRI, percent index of relative importance).

\begin{tabular}{|c|c|c|c|c|c|c|c|c|c|c|c|c|}
\hline \multirow[b]{2}{*}{ Prey } & \multicolumn{4}{|c|}{ Total } & \multicolumn{3}{|c|}{ Winter } & \multirow[b]{2}{*}{$\%$ IRI } & \multicolumn{4}{|c|}{ Spring } \\
\hline & $\% \mathrm{FO}$ & $\% \mathrm{~W}$ & $\% \mathrm{~N}$ & $\%$ IRI & $\% \mathrm{FO}$ & $\% \mathrm{~W}$ & $\% \mathrm{~N}$ & & $\% \mathrm{FO}$ & $\% \mathrm{~W}$ & $\% \mathrm{~N}$ & $\%$ IRI \\
\hline \multicolumn{13}{|l|}{ TELEOST FISH } \\
\hline \multicolumn{13}{|l|}{ Ophidiidae } \\
\hline Raneya brasiliensis & 58.6 & 21.7 & 49.7 & 12.4 & 33.3 & 7.5 & 15.4 & 8.2 & 76.5 & 33.4 & 56.7 & 23.3 \\
\hline \multicolumn{13}{|l|}{ Batrachoididae } \\
\hline Porichthys porosissimus & 20.7 & 6.7 & 11.3 & 8.9 & 16.7 & 11.1 & 42.3 & 38.3 & 23.5 & 3.1 & 5.2 & 7.0 \\
\hline \multicolumn{13}{|l|}{ Scianidae } \\
\hline Cynoscion guatucupa & 17.2 & 34.9 & 29.6 & 38.0 & - & - & - & - & 29.4 & 63.3 & 35.1 & 66.2 \\
\hline Umbrina canosai & 3.4 & - & 0.6 & - & - & - & - & - & 5.9 & - & 0.7 & - \\
\hline \multicolumn{13}{|l|}{ Eleginopidae } \\
\hline Eleginops maclovinus & 10.3 & 35.7 & 2.5 & 37.6 & 25.0 & 79.7 & 15.4 & 45.4 & - & - & - & - \\
\hline \multicolumn{13}{|l|}{ Macrouridae } \\
\hline Caelorinchus fasciatus & 6.9 & - & 0.6 & - & - & & - & - & 11.8 & - & 0.7 & - \\
\hline \multicolumn{13}{|l|}{ Carangidae } \\
\hline Trachurus lathami & 6.9 & 0.95 & 1.2 & 3.3 & 8.3 & 1.81 & 3.8 & 8.1 & 5.9 & 0.3 & 0.7 & 3.4 \\
\hline Scorpenidae & 3.4 & - & - & - & 8.3 & - & 23.1 & - & - & - & - & - \\
\hline Scianidae & 3.4 & - & - & - & - & - & - & - & 5.9 & - & 0.7 & - \\
\hline Unidentified & 41.4 & - & - & - & 41.7 & - & - & - & 41.2 & - & - & - \\
\hline \multicolumn{13}{|l|}{ CEPHALOPODS } \\
\hline \multicolumn{13}{|l|}{ Loliginidae } \\
\hline Loligo gahi & 42.1 & 54.8 & 21.4 & 41.9 & 42.9 & 100 & 66.7 & 100 & 50 & 52.4 & 19 & 29.4 \\
\hline \multicolumn{13}{|l|}{ Octopodidae } \\
\hline Octopus tehuelchus & 36.4 & 45.2 & 77 & 58.1 & - & - & - & - & 66.7 & 47.6 & 81 & 70.6 \\
\hline Ommastrephidae & 4.5 & - & 1.6 & - & 14.3 & - & 33.3 & - & - & - & - & - \\
\hline Unidentified & 21 & - & - & - & 42.9 & - & - & - & 8.3 & - & - & - \\
\hline
\end{tabular}

On the other hand, crustaceans ocurred only in 5\% of the scats that presented hard remains.

Spring. In spring, 262 otoliths (rate: 8.2 otoliths per scat) from six species were retrieved from the 32 scats containing fish remains. $R$. brasiliensis was the most frequent and abundant prey $(\% \mathrm{FO}=76.5$ and $\% \mathrm{~N}=56.7)$, followed by $C$. guatucupa $(\% \mathrm{FO}=29.4$ and $\% \mathrm{~N}=35.1)$. These two species also showed the higher values of relative importance index, contributing together almost $90 \%$ to the total IRI.

Cephalopods were represented by 105 beaks (upper $\mathrm{n}=47$ and lower $\mathrm{n}=58$ ). Two species were identified: the squid L. gahi and the octopod O. tehuelchus, the latter being the most frequent and abundant cephalopod prey $(\% \mathrm{FO}=66.7$ and $\% \mathrm{~N}=81 \%)$. Beaks were recovered at a rate 8.75 per scat containing cephalopod remains.

As regards to crustaceans, these were the least

Tab. II. Estimated total length of the main prey fish of Otaria flavescens (Shaw, 1800) on Río Negro province, Argentina

\begin{tabular}{lccc}
\hline & \multicolumn{3}{c}{ Total Length $(\mathrm{mm})$} \\
\cline { 2 - 4 } Fish prey taxon & $\mathrm{n}$ & Mean \pm SD & Range \\
\hline Raneya brasiliensis & 93 & $160.4 \pm 31.2$ & $103.6-253.2$ \\
Porichthys porosissimus & 14 & $161.4 \pm 30.9$ & $120.4-233.8$ \\
Cynoscion guatucupa & 85 & $159 \pm 80.8$ & $60.5-446.9$ \\
\hline
\end{tabular}

frequent prey taxon, ocurring in $17.6 \%$ of scats.

The trophic spectrum diversity calculated was highest in spring than in winter $\left(\mathrm{H}^{\prime}=4.7\right.$ in spring vs. $\mathrm{H}^{\prime}$ $=0.29$ ). There were not significant differences between seasons in the frequency of occurrence of the main prey taxa considered $\left(\mathrm{X}_{2}{ }_{2}=4.7, \mathrm{p}>0.01\right)$.

\section{DISCUSSION}

Fish were the most frequent prey throughout the whole study period occurring in $96 \%$ of scats containing food remains, followed by cephalopods. The presence of crustaceans was negligible. This is in line with previous dietary studies of $O$. flavescens, where fish were also the dominant prey taxa (George-Nascimiento et al., 1985; Thompson et al., 1998; Koen Alonso et al., 2000; NAYA et al., 2000; SuÁrez et al., 2005; OliveIRA et al., 2008). The low frequency of occurrence and scarce number of crustacean specimens found in scats, and the fact that the most frequent prey taxa (fish and octopods) are, at least partially carcinophagous, lead us to infer that, for this locality, crustaceans would represent secondary prey (prey of prey). However, it is worth mentioning that crustaceans have been reported as an important food item of $O$. flavescens at other localities of its distributional range (Thомpson et al., 1998; Sото et al., 2006).

Previous dietary reports of $O$. flavescens 


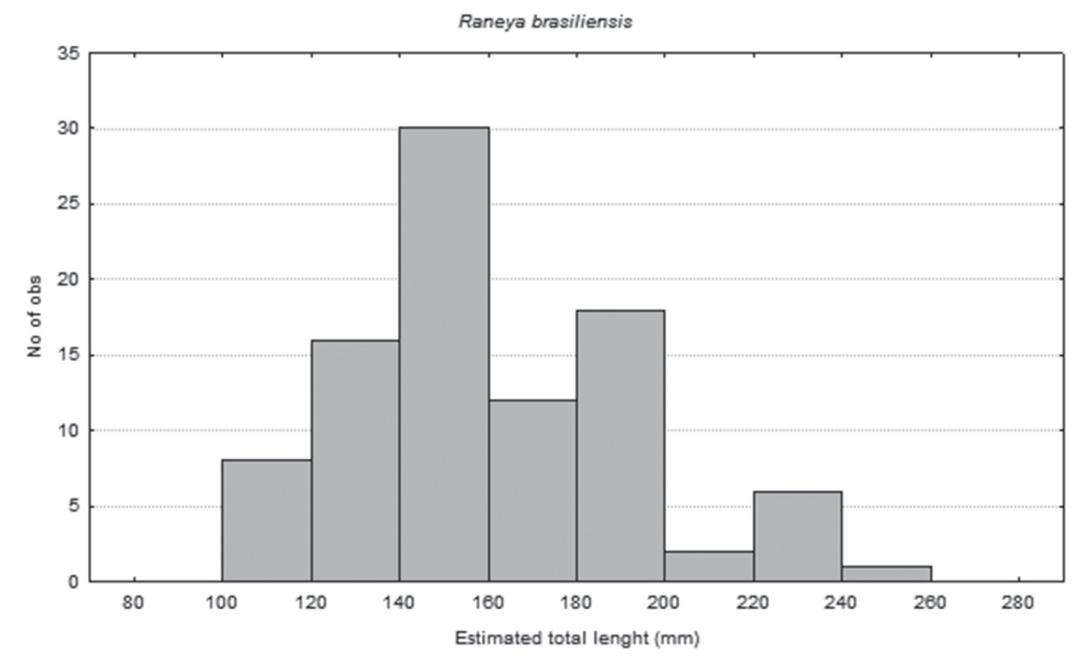

Fig. 3. The frequency of estimated total lengths of Raneya brasiliensis taken by Otaria flavescens (Shaw, 1800).

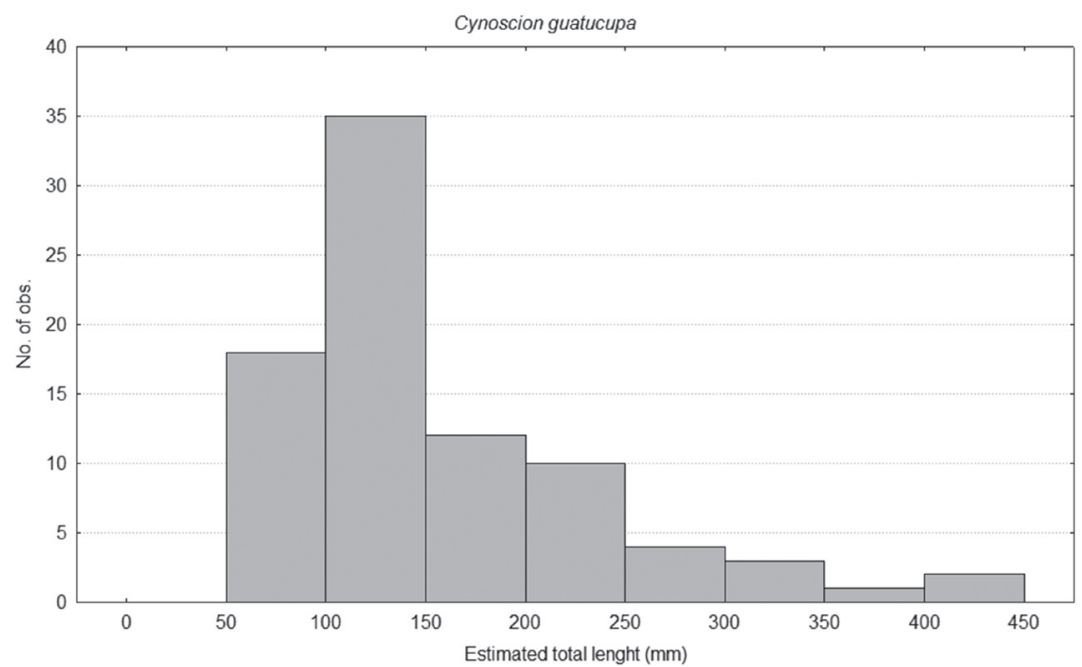

Fig. 4. The frequency of estimated total lengths of Cynoscion guatucupa taken by Otaria flavescens (Shaw, 1800).

characterized this species as an opportunistic and broadspectrum predator. This is consistent with the results obtained in our study since there were seven species of fish and three of cephalopods as part of the diet. Raneya brasiliensis was the most frequent and abundant fish species consumed by $O$. flavescens throughout the whole study period. This prey is a key link in the Southwestern Patagonian higher level food web and has been reported as a common prey item in the diet of marine mammals, marine birds and fishes (Gosztonyi et al., 2007). However, in terms of biomass, E. maclovinus and $C$. guatucupa represented the two most important fish prey taxa in winter and spring respectively. Analyzing the habitat of the dominant prey taxa of $O$. flavescens, we surmise that this otariid fed mainly on demersal and benthic species, associated with the continental shelf and the shelf break. In agreement with this, studies based on satellite telemetry in lactating female and sub-adult male South American sea lions at Peninsula Valdes reported that the foraging trips of males and females were confined to temperate waters of the Patagonian continental shelf, with males foraging in those areas located near the edge of the continental shelf and lactating females associated to coastal zone (WERNER \& CAMPAGna, 1995; THOMPSON et al., 1998; CAmpagna et al., 2001). Moreover, Drago et al. (2009), studying the ontogenetic change in the diet of male and female sea lions on the Patagonian coast of Chubut province, through stable isotope analysis, suggested that the consumption of benthic prey items increased from post-weaning to adulthood in both sexes. Furthermore, subadult and adult males had a much more benthic diet than females of the same developmental stage. It is worth mentioning that in the present study no significant differences were found in the frequencies of occurrence of the major prey taxa between seasons (winter vs. spring). Few studies have addressed the issue of seasonal variation in the diet of $O$. flavescens. SUÁREZ et al. (2005), analyzing the diet of this species over a year in Puerto Quequen (38 $32^{\circ}$ S, 58 $42^{\circ} \mathrm{O}$ ), south of Buenos Aires province, Argentina, found seasonal differences in its diet though they did not specify which seasons were involved. Furthermore, these same authors also reported significant differences in the frequency of occurrence of only two fish prey species which, together, did not 
contribute more than $15 \%$ in terms of numbers to the overall fish diet of the seals.

In the spring season, the diet of sea lions was characterized by a higher amount of prey, as reflected by the higher rate of otoliths and beaks per scat, and a greater diversity of prey species. This might be related either to a higher feeding activity of sea lions or an increased availability of prey in the area, or both factors combined, during this season. Future dietary studies of $O$. flavescens should include a comparative analysis of seasonal variation. This would be the next fundamental step to corroborate or refute this suggestion.

Of the three fish species that together accounted for more than $90 \%$ of the amount of fish preyed by $O$. flavescens, throughout the study period, only $C$. guatucupa is target of commercial fisheries (COUSSEAU \& Perrota, 2004). This is one of the most abundant target species of a multispecific demersal fishery denominated "coastal fish assemblage" or "variado costero" which operates on the coasts of Buenos Aires and which consists of a dozen species (Lopez CAzorla, 2000; CARozza et al., 2001; RUARTE \& SAEZ, 2008). The estimated average total length of $C$. guatucupa predated by $O$. flavescens was $15.9 \mathrm{~cm}$ and almost $90 \%$ of individuals preyed upon did not exceed $18 \mathrm{~cm}$. This would indicate that sea lions preyed mainly on juveniles that did not exceed one year of age (Lopez CAZorla, 2000). The most common sizes of fish landings are between 35 and $45 \mathrm{~cm}$ in total length (Cousseu \& Perrotta, 2004). Nevertheless it is remarkable that the use of different age classes of the same resource, at different times or spatial locations do not imply less intensity of the interaction (SzTEREN et al., 2004). Therefore there might be an overlap between $O$. flavescens and fisheries in the use of C. guatucupa as a prey resource, though not in size since this species would prey on juveniles of the southern stocks of C. guatucupa which inhabit the coastal zone (JAUREGUIZAR et al., 2006; Militelli \& MACHI, 2006; VolPedo et al., 2007).

In summary the diet of $O$. flavescens at Punta Bermeja was diverse, corroborating its generalist and opportunistic feeding behaviour. The seasonal variation in the composition of the fish and cephalopod diet probably reflected the different prey availability and habitat use, being the coastal zone of the continental shelf the main foraging area, preying upon a wide range of species, mainly those of demersal and benthic habits. This study attempts to enhance the knowledge of the trophic role of $O$. flavescens in the southwestern Atlantic marine ecosystem. This in turn, constitutes an important tool for the management and conservation of this species.

Acknowledgements. The authors would like to thank the Consejo de Ecología y Medio Ambiente (CODEMA) and Dirección de Fauna of Río Negro Province for providing permits for sampling in the rookery. We also thank to Mauricio Failla, Roberto Lini and Ramon Conde for logistic support and the group of rangers of Río Negro Province, for field support. We are also indebted to Dr. Carlos
H. Lenzi (Fundación para el Desarrollo de la Patagonia) for partial financial support of field campaigns. We are also grateful to two anonymous reviewers whose critical comments greatly improved the manuscript.

\section{REFERENCES}

Baldas, M. I.; Pérez Macri, G.; Volpedo, A.V.; Echeverría, D. D. 1997. Morfología de la sagita de peces marinos de la costa bonaerense de la Argentina I: Carangidae, Scianidae Mullidae. Atlântica 19:99-112.

Begon, M.; HARPer, J.; Townsend, C. R. 1996. Ecology: Individuals, Populations and Communities. Oxford, Blackwell. 1068p.

Campagna, C.; Werner, R.; Karesh, W.; Marín, M. R.; Koontz, F.; Cook, R. \& Koontz, C. 2001. Movements and location at sea of South American sea lions (Otaria flavescens). Journal of Zoology 257:205-220.

Carozza, C.; Navarro, L.; Jaureguizar, A.; Lasta, C. \& Bertolotti, M. 2001. Asociación íctica costera bonaerense "Variado Costero". Informe Técnico DNI-INIDEP 48:1-28.

Clarke, M. R. 1986. A handbook for the identification of cephalopods beaks. Oxford, Clarendon Press. 273p.

Cortes, E. 1997. A critical review of methods of studying fish feeding based on analysis of stomach contents: application to elasmobranch fishes. Canadian Journal Fisheries and Aquatic Science 54:726-773.

Cousseau, M. B. \& Perrotta, R. G. 2004. Peces marinos de Argentina. Biología, distribución, pesca. Mar del Plata, INDEP. $167 \mathrm{p}$.

Crespo, E. A. \& Pedraza, S. N. 1991. Estado actual y tendencia de la población de lobos marinos de un pelo (Otaria flavescens) en el litoral norpatagonico. Ecología Austral 1:87-95.

Crespo, E. A.; Oliva, D.; Dans, S. \& Sepulveda, M. 2012. Estado de situación del lobo marino común en su área de distribución. Valparaiso, Sello Editorial Universidad de Valparaiso. 200p.

Daneri, G. A.; Carlini, A. R.; Hernández, C. M. \& Harrington, A. 2005. The diet of Antarctic fur seals, Arctocephalus gazella, at King George Island, during the summer-autumn period. Polar Biology 28:329-333.

Daneri, G. A.; Carlini, A. R.; Harrington, A.; Balboni, L. \& HernÁNDEZ, C. M. 2008. Interannual variation in the diet of nonbreeding male Antarctic fur seals, Arctocephalus gazella, at Isla 25 de Mayo/King George Island". Polar Biology 31:1365-1372.

Dans, S.; Crespo, E.; Pedraza, S.; Gonzáles, R. \& García, N. 1996. Estructura y tendencia de los apostaderos de lobos marinos de un pelo (Otaria flavescens) en el norte de Patagonia. Informes Técnicos del Plan de Manejo Integrado de la Zona Costera Patagónica 13:1-16.

Dans, S. L.; Crespo, E. A.; Pedraza, S. N. \& Koen Alonso, M. 2004 Recovery of the South American sea lion population in northern Patagonia. Canadian Journal Fisheries and Aquatic Science 61:1681-1690.

Dellinger, T. \& Trillmich, F. 1999. Fish prey of the sympatric Galápagos fur seals and sea lions: seasonal variation and niche separation. Canadian Journal Zoology 77:1204-1216.

Drago, M.; Cardona, L.; Crespo, E. A. \& Aguilar, A. 2009. Ontogenic dietary changes in South American sea lions. Journal of Zoology 279:251-261.

Drago, M. L.; Cardona, E. A.; Crespo, N. A.; García, N.; Ameghino, S. \& Aguilar, A. 2010. Change in the foraging strategy of female South American sea lions (Carnivora: Pinnipedia) after parturition. Scientia Marina 74(3):589-598

George-Nascimento, M. F.; Bustamante, R. A. \& Oyarzun, R. C. 1985. Feeding ecology of the Southern sea lion Otaria flavescens Shaw, 1800: food contents and food selectivity. Marine Biology Progress Series 21:135-143.

Gosztonyi, A. E.; KubA, L. \& Mansur, L. E. 2007. Estimation of body size using morphometric relationships of head bones, pectoral fin bones and bony precaudal distance in Raneya brasiliensis (Kaup 1856) (Pisces, Ophidif formes, Ophidiidae) in Patagonian waters. Revista de Biología Marina y Oceanografía 42(1): 1-5.

Hecht, T. 1987. A guide to the otoliths of Southern Ocean fishes. South African Journal of Antarctic Research 17:1-87.

Jaureguizar, A. J.; Ruarte, C. \& Guerrero, R. 2006. Environmental influence on the spatial distribuction of age-classes stripped 
weakfish (Cynoscion guatucupa) along an estuarinemarine gradient, South America. Estuarine, Coastal and Shelf Science 67(1-2):82-92.

Koen Alonso, M.; Crespo, E. A. \& Pedraza, S. N. 2000. Food habits of the South American sea lion, Otaria flavescens, off Patagonia, Argentina. Fishery Bulletin 98:250-263.

Lewis, R.; O’Connell, T.; Lewis, M.; Campagna, C. \& Rus Hoelzel, A. 2006. Sex-specific foraging strategies and resource partitioning in the southern elephant seal (Mirounga leonina). Proceedings of the Royal Society Biological Science 273:2901-2907.

Lopez CAzorla, A. 2000. Age structure of the population of weakfish Cynoscion guatucupa (Cuvier) in the Bahia Blanca waters, Argentina. Fisheries Research 1025(1-3):1-8.

Militelli, M. I. \& Machi, G. J. 2006. Spawning and fecundity of striped weakfish, Cynoscion guatucupa, in the Río de la Plata estuary and adjacent marine waters, Argentina-Uruguay. Fisheries Research 77:110-114

NAYA, D. E.; VArgas, R. \& ARIM, M. 2000. Análisis preliminar de la dieta del león marino del sur (Otaria flavescens) en Isla de Lobos, Uruguay. Boletín de la Sociedad Zoológica de Uruguay 12:14 21.

Oliveira, L. R.; Ott, P. H. \& Malbarba, L. R. 2008. Ecologia alimentar dos pinípedes do suldo Brasil e uma avaliação de suas interações com atividades pesqueiras. In: FURTADO, N. org. Ecologia de Mamíferos. Londrina, Technical Books. p. 97-116.

Pineda, S. E.; Aubone, A. \& Brunetti, N. 1996. Identificación y morfometría comparada de las mandíbulas de Loligo gahi y Loligo sanpaulensis (Cephalopoda, Loliginidae) del Atlantico Sudoccidental. Revista de Investigación y Desarrollo Pesquero 10:85-99.

Pinkas, L.; Oliphant, M. S. \& Iverson, I. L. K. 1971. Food habits of albacore, bluefin tuna and bonito in California waters. Fishery Bulletin 152:1-105

Raclot, T.; Groscolas, R. \& Cherel, Y. 1998. Fatty acid evidence for the importance of myctophid fishes in the diet of king penguins, Aptenodytes patagonicus. Marine Biology 132:523-533.

ReID, K. \& Arnould, J. P. Y. 1996. The diet of Antartic fur seals Arctocephalus gazella during the breeding season at South Georgia. Polar Biology 16:105-114.

Reyes, L. M.; Crespo, E. A. \& Szapkievich, V. 1999. Distribution and population size of the southern sea lion (Otaria flavescens) in central and southern Chubut, Patagonia, Argentina. Marine Mammals Science 15(2):478-493.

Romero,M.A.;Dans, S.L.; GonzÁlez, R.;Svendsen, G. M.; García, N.\& Crespo, E. A. 2011. Solapamiento trófico entre el lo bomarino de un pelo Otaria flavescens y la pesquería de arrastre demersal del Golfo San Matías, Patagonia, Argentina. Latin American Journal of Aquatic Science 39(2):344-358.

Ruarte, C. O. \& SÁEz, M. B. 2008. Estudio preliminar sobre la estructura de edades y el crecimiento de la pescadilla de red (Cynoscion guatucupa, Pisces, Sciaenidae) en el área sur de la Provincia de Buenos Aires. Revista de Investigación y Desarrollo Pesquero 19:37-44.

Schiavini, A. C. M.; Crespo, E. A. \& Szapkievich, V. B. 2004. Status of the population of South American sea lion (Otaria flavescens Shaw, 1800) in southern Argentina. Mammalian Biology 69:111.

Sergeant, D. E. 1973. Feeding, growth, and productivity of Northwest Atlantic harp seals (Pagophilus groenlandicus). Journal of the Fisheries Research Board of Canada 30(1):17-29.

Soto, H. K.; Trites, A. W. \& Arias Schreiber, M. 2006. Changes in diet and maternal attendance of South American sea lions indicate changes in the marine environment and prey abundance. Marine Ecology Progress Series 312:277-290.

Suárez, A. A.; Sanfelice, D.; Cassini, M. H. \& Cappozzo, H. L. 2005. Composition and seasonal variation in the diet of the South American sea lion (Otaria flavescens) from Quequén Argentina. The Latin American Journal of Aquatic Mammals 4(2): 163 174.

SzTeren, D.; NAYA, D. E. \& Arim, M. 2004. Overlap between pinniped summer diet and artisanal fishery catches in Uruguay. The Latin American Journal of Aquatic Mammals 3(2):119-125.

Thompson, D. C.; Duck, D.; McConnell, B. J. \& Garrett, J. 1998 Foraging behaviour and diet of lactating female southern sea lions (Otaria flavescens) in the Falkland Islands. Journal of Zoology 246:135-146.

Torno, A. E. 1976. Descripción y Comparación de los otolitos de algunas familias de peces de la plataforma Argentina. Revista del Museo Argentino de Ciencias Naturales "Bernardino Rivadavia", Zoología 12:27-43.

Volpedo, A.V. \& EcheverríA, D. D. 2000. Catálogo y claves de otolitos para la identificación de peces del Mar Argentino. Peces de importancia comercial. Buenos Aires, Editorial Dunken. 90p

Volpedo, A.V.; Miretzky, P. A.; Fernández Cirelli, A. 2007. Stocks pesqueros de Cynoscion guatucupa y Micropogonias furnieri de la costa atlántica de Sudamérica: comparación entre métodos de identificación. Memoria de la Fundación La Salle de Ciencias Naturales 165:115-130.

Werner, R. \& Campagna, C. 1995. Diving behaviour of lactating southern sea lions (Otaria flavescens) in Patagonia. Canadian Journal of Zoology 73:1975-1982.

Xavier J. C. \& Cherel, Y. 2009. Cephalopod beak guide for the Southern Ocean. Cambridge, British Antarctic Survey. 129p

XimÉneZ, I. 1976. Dinámica de la Población de Otaria flavescens (Shaw) en el Área de Península Valdés y Zonas Adyacentes Provincia del Chubut, República Argentina. Informe Técnico del Centro Nacional Patagónico 1.4.1.:1-52. 